\title{
Employment law cases
}

Addison Lee Ltd v. Gascoigne (2018). EAT.

Adkins and Others v. Lex Autolease Limited (2017). Employment Tribunal. 1

March 2017.

Aslam and Others v. Uber BV and Others (2016). Employment Tribunal. 28

October 2016. 2017 EAT. 2018 Court of Appeal.

Autoclenz Ltd v. Belcher and Others (2011). IRLR. 820.

Boxer v. Excel Group Ltd (in liquidation) (2017). Employment Tribunal.

Byrne Brothers (Formmork) Ltd v. Baird (2002). IRLR. 96.

Cotswold Developments Construction Ltd v. Williams (2006). IRLR. 181.

Demhurst v. Citysprint UK Ltd. (2017). Employment Tribunal. 1 May 2017.

Independent Workers' Union of Great Britain (IWGB) v. RoofFoods $t / a$

Deliveroo (2017). Central Arbitration Committee, TUR1/985(2016), 14.11.2017.

Fivraj v. Hashwani (2011). IRLR. 827.

Lange and Others v. Addison Lee Limited (2017). Employment Tribunal. 2018 EAT.

Leyland and others v. Hermes Parcelnet Ltd. (2018). Employment Tribunal.

Obi v. Verma and Rice Shack Ltd. (2017). Employment Tribunal.

Pimlico Plumbers Limited and Another v. Smith (2018). UKSC. 29.

Protectacoat Firthglow Ltd v. Szilagyi (2009). IRLR. 365.

$R$ (on the Application of Unison) v. Lord Chancellor (2017). UKSC. 51.

SW Global Resourcing Ltd v. Docherty and Another (2012). IRLR. 727. EAT

and (2013) CSIH 72 (Inner House of Court of Session in Scotland).

Young and Woods Ltd v. West (1980). IRLR. 201. 